\title{
NEUTRACUETICAL EVALUATION OF BOERHAVIA DIFFUSA L.
}

\author{
Original Article
}

\author{
JUNA BEEGUM G. R. ${ }^{1}$, SUGUNAN V. S. ${ }^{2 *}$ S. SUHARA BEEVY ${ }^{1}$
}

1Department of Botany, University of Kerala, Kariavattom, ${ }^{2}$ Department of Zoology, University College, Thiruvananthapuram Email: junagr@gmail.com

Received: 25 Sep 2016, Revised and Accepted: 25 Nov 2016

\begin{abstract}
Objective: Boerhavia diffusa a tropical herb has been a subject of keen interest in phytochemical and pharmacological research due to its excellent medicinal values. The stress and need for quality control and standardisation of medicinal preparations from plants is gaining more importance today in view of the commercialization of drug formulations.
\end{abstract}

Methods: WHO recommends various physicochemical, proximate and nutritive standards so that uniformity in composition and effectiveness is maintained. All the analysis was done using standard protocols.

Results: The nutraceutical evaluation of the plant gives an insight into its value as a medicinal as well as highly nutritious one, safe for consumption both as a medicine and as a natural source for antioxidant activities.

Conclusion: Thus the present finding suggests that $B$. diffusa have a promising potential not only to cure ailments but to maintain a healthy life.

Keywords: Boerhavia diffusa, Commercialization, Physicochemical, Proximate, Standardization

(C) 2016 The Authors. Published by Innovare Academic Sciences Pvt Ltd. This is an open access article under the CC BY license (http://creativecommons.org/licenses/by/4.0/]

DOI: http://dx.doi.org/10.22159/ijcpr.2017v9i1.16626

\section{INTRODUCTION}

Medicinal plants are part and parcel of human society to combat diseases, from the dawn of civilisation. Before the advent of modern medical practices plants were the only source of intervention in treating diseases. The main issue associated with the manufacture and utilization of herbal products is the lack of standards in the preparation based on such plants. When a plant extract is to be considered as a nutraceutical, the bioactive principles responsible for the effect should be present in the right amount and proportions. Continuous research and feedback helps in prescribing standards. Standardisation ensures that the process of production of natural medicines or extracts is guaranteed for consistency of active compound at a satisfied level for its quality control yardstick [1]. The most important step in the standardisation of herbal drugs is the correct taxonomic identification of the plant, whether in fresh, dried or powdered state [2]. Yelne et al., (2000) and Goyal et al., $(2010)[3,4]$ reported the use of the species Trianthema portulacastrum $\mathrm{L}$ as an adulterant of $B$. diffusa for ayurvedic preparations, this type of adulterations can be avoided by the pharmacological studies of the plant.

As various medicinal plants are used as food as well as medicine, the worth of the plant can be evaluated by the nutritional significance and is an added advantage during its consumption [5]. In addition to it being used as an herbal medicine, B. diffusa is consumed as a [6]. Various ethnopharmacological reports emphasise its role in disorders of the reproductive, gastrointestinal, respiratory, urinary, hepatic and cardiovascular system as well as in the treatment of cancer. The survey of the literature indicated that no serious evaluation of pharmacological and phytochemical parameters of $B$. diffusa had been carried out $[7,8,4]$. Thus a detailed evaluation becomes necessary for further research on this plant particularly in the field of pharmacognosy, not only because of their widespread uses but also to evaluate whether these components that may cause toxic reactions or other adverse interactions.

\section{MATERIALS AND METHODS}

\section{Collection of plant material and preparation of extract}

Fresh whole plants of $B$. diffusa were collected from the Kariavattom campus, University of Kerala, Trivandrum. The specimen was scientifically identified, and a voucher specimen (No: KUBH 5856) has been deposited at the Department of Botany, University of
Kerala. The materials were washed with distilled water and air dried in the shade for two weeks at room temperature. Dried sample was milled into powder using an electric blender. The powder was stored in airtight container in a refrigerator until further analysis. $100 \mathrm{gm}$ of dried powdered sample was extracted with $1000 \mathrm{ml}$ of ethanol for $12 \mathrm{~h}$ in a Soxhlet extraction apparatus. Filtered extract was evaporated using a rotary evaporator at $40-50{ }^{\circ} \mathrm{C}$, under reduced pressure.

\section{Organoleptic analysis}

The physical state, colour, taste and odour of the fresh plant, as well as the powder of B. diffusa, were noted in the organoleptic analysis [9].

\section{Physicochemical characterization}

The different physicochemical parameters used to assess the quality of medicinal plant material as a drug include loss on drying [10], dry matter [11], total ash, acid insoluble/soluble ash [12], water soluble ash, water insoluble ash, sulphated ash [13], water soluble extractives, alcohol soluble extractives [14], foaming index and swelling index [10].

\section{Determination of micrometric properties}

The Micrometric analysis includes the determination of bulk density, tapped density ([14], Hausner ratio [15] and compressibility index [16].

\section{Proximate analyses}

In Proximate analyses, moisture content [10], crude fibre [17], total carbohydrate [18], reducing sugar [19], total protein [20], total lipids [21], fatty acid [22], vitamin A [23], thiamine, riboflavin [24], niacin [25], vitamin C [23], vitamin E [26], amino acids [27] and energy value [28] were determined.

\section{Analysis for quantifying minerals}

Mineral profiling was used to determine the macro elements $(\mathrm{Mg}$, $\mathrm{Na}, \mathrm{Ca}, \mathrm{K})$, microelements ( $\mathrm{Zn}, \mathrm{Mn}, \mathrm{Fe})$ and heavy metals $(\mathrm{Pb}, \mathrm{Cu}, \mathrm{Cd})$ using Atomic Absorption Spectrophotometer (AAS) (perkin Elmer India Pvt Ltd. Model: Pinnacle 900H) [29].

\section{Determination of antinutrients}

Antinutrient analysis includes estimation of tannins, saponins, oxalates and phytic acid [30]. 


\section{RESULTS}

\section{Organoleptic properties}

The fresh plant of B. diffusa was dark green in colour, with the phenolic smell and little bitter, taste. The whole plant drug powder was solid, free flowing in nature and green in colour, with no characteristic odour. It was little bitter in taste.

\section{Physico-chemical characterization}

Physico-chemical characterization revealed the following. Foreign matter in $B$. diffusa whole plant powder was found to be very low $(1.0 \pm 0.2 \%)$. The foaming index was more than 100 units and no considerable swelling was observed when hydrated.

The total ash value was high $23.09 \pm 0.7 \%$. Acid-insoluble ash and water soluble ash were $0.6 \pm 0.04 \%$ and $4.70 \pm 0.1 \%$ respectively. Alcohol soluble extractives values $(16.60 \pm 0.11 \%)$ were higher when compared to water soluble $0.35 \pm 0.20 \%$ ).

Results of the physicochemical parameters are shown in Graph 1.

\section{Micrometric properties}

The powder showed good flow rate as confirmed by a high Hausner ratio $1.07 \pm 0.41$ and compressibility index $7.48 \pm 0.72$. Micrometric properties of the plant powder are given in the table 1.

\section{Proximate analyses}

In the proximate analysis, the moisture content of the powdered sample of was $13.09 \pm 0.17 \%$. The nutritive parameters like carbohydrates, fats and proteins were found to be $30.90 \pm 0.51$, $1.61 \pm 0.01$ and $15.20 \pm 0.3 \mathrm{mg} / \mathrm{g}$ respectively. Niacin, the major vitamin in the plant was estimated to be $0.96 \pm 0.01 \mathrm{mg} / \mathrm{g}$ fresh sample. Total free amino acid was quantified to be $4.7 \pm 0.91$ and energy value as $198.89 \mathrm{kcal}$ per $100 \mathrm{~g}$ of the fresh sample $(\mathrm{w} / \mathrm{w})$. Proximate characteristics of the plant are represented graph 2 and 3 .

\section{Mineral analysis}

The major elements present in B. diffusa are Magnesium, Sodium and Potassium at a concentration of $142.9 \mathrm{mg} / 100 \mathrm{~g}, 75.9 \mathrm{mg} / 100 \mathrm{~g}$ and $52.7 \mathrm{mg} / 100 \mathrm{~g}$ respectively. However, the heavy metals like Lead $(1.25$ $\mathrm{mg} / 100 \mathrm{~g})$, Copper $(3.9 \mathrm{mg} / 100 \mathrm{~g})$ and Cadmium $(0.28 \mathrm{mg} / 100 \mathrm{~g})$ were only in trace amounts. The amount of macro and micro minerals present in the plant is graphically represented in fig. 4.

\section{Determination of anti-nutrients}

Anti-nutrient analysis revealed the moderate amount of tannin and oxalates at a concentration of $16 \mathrm{mg} / \mathrm{g}$ and $4.7 \mathrm{mg} / \mathrm{g}$ in dried samples of $B$. diffusa. In fresh wet samples, low amounts of phytic acid and saponin at $1.59 \%$ and $0.09 \mathrm{mg} / \mathrm{g}$ were detected.

Table 1: Micrometric analysis

\begin{tabular}{lll}
\hline S. No. & Micrometric properties & Amount present \\
\hline 1. & Bulk density g/ml & $0.34 \pm 0.02$ \\
2. & Tapped density g/ml & $0.17 \pm 0.01$ \\
3. & Hausner ratio & $1.07 \pm 0.41$ \\
4. & Compressibility index & $7.48 \pm 0.72$ \\
\hline
\end{tabular}

Values are mean $\pm \mathrm{SE} ; \mathrm{n}=3$

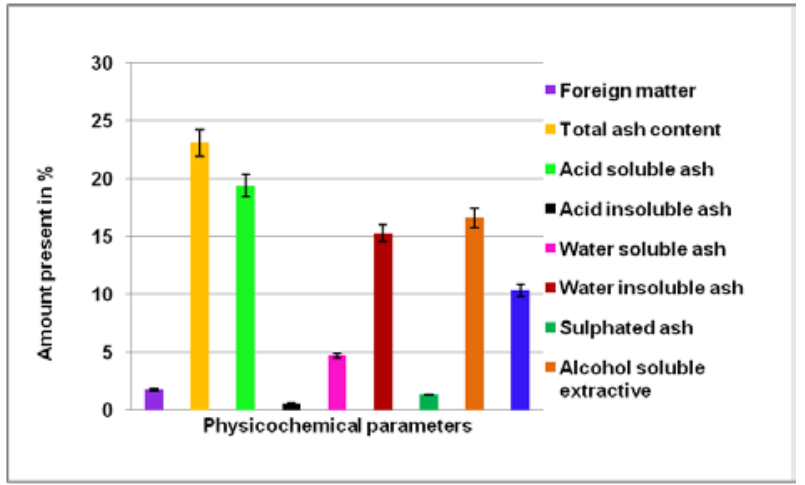

Fig. 1: Determination of physicochemical properties

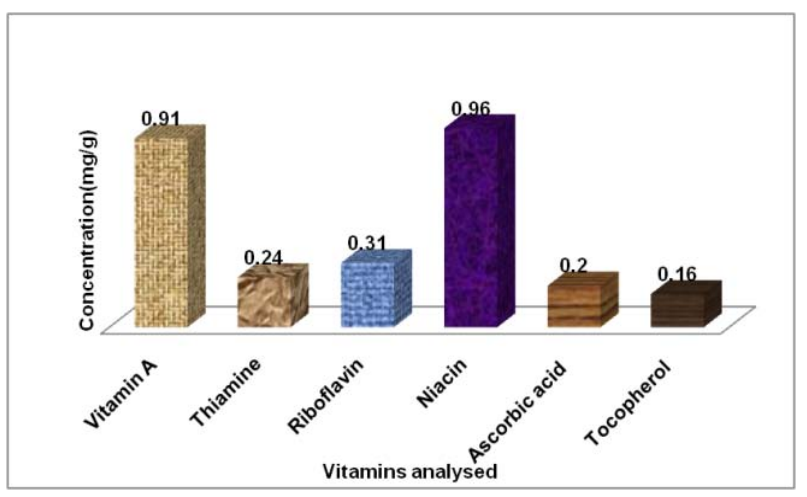

Fig. 2: Vitamin analysis in $B$ diffusa

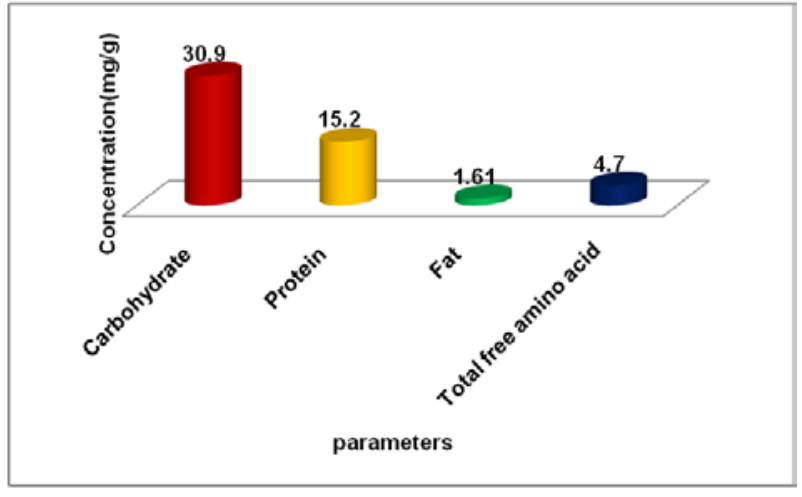

Fig. 3: Nutritive analysis of $B$. diffusa

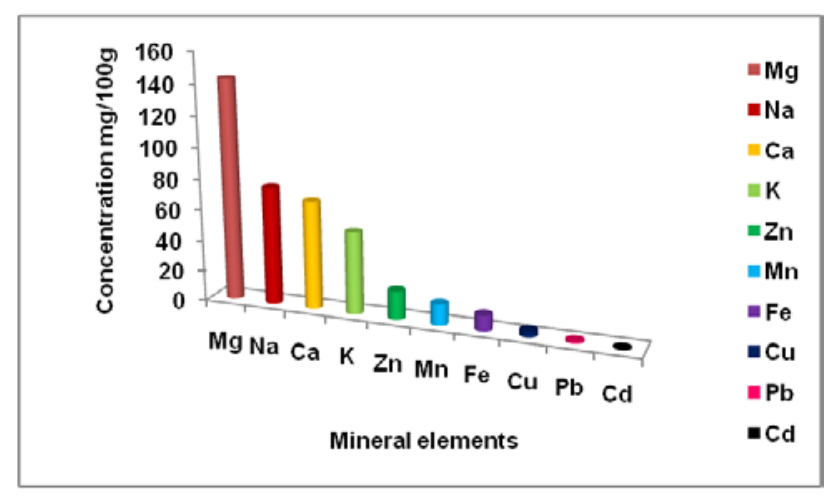

Fig. 4: Mineral analysis in B. diffusa 


\section{DISCUSSION}

\section{Organoleptic study}

Organoleptic analysis helps to assess the physical and chemical quality of the plant sample. The organoleptic study of the plant $B$. diffusa revealed the edible nature because of the lack of pungent odor and taste. The present result confirmed the findings of Ramteke et al. (2011).

\section{Physicochemical characterization}

The physicochemical property of a drug is an important parameter in detecting adulteration or improper handling of drugs [32]. In the present study, the amount of foreign matter detected from the plant powder was very low as per WHO (2002) that is the permissible limit for foreign matter is not more than $2 \%$. The present investigation supports the findings of Meena et al., (2010) and Malhotra et al., (2013) [33, 34].

The high foaming index reflects the presence of saponin in the plant and absence of mucilage may be the reason for low swelling index value observed in B. diffusa and the parameter can be used for the detection of purity of the crude drug. High ash value in the plant represents the inorganic part of the plant [35]. The results of ash value suggested that $B$ diffusa was a good source of mineral elements. The amount of inorganic material can be estimated by detecting the water soluble portion of the total ash.

The oxides and carbonates during consistent sulphated ash production were converted into sulphates and are used for the detection of low-grade products in the drug. The present investigation on ash values supports the earlier reports of Bharathi et al., (2014), Ujowundu et al., (2008) and Malhotra et al., (2013) [7, $34,36]$.

Extractive values are useful for the evaluation especially when the constituents of the drugs cannot be readily estimated by any other means. The present investigation noticed higher extractive value for alcohol compared to water. Higher alcohol soluble extractive value implies that ethanol is a better solvent of extraction than water for the formulation.

\section{Determination of micrometric properties}

The widespread use of plants as powdered drug in the pharmaceutical industry has generated a variety of methods such as determination of bulk density, tapped density, HR value and CI value for characterising powder flow. All the parameters analysed in micrometric property of $B$. diffusa plant powder revealed good flow rate and this property plays an important role in the packaging of individual drugs and formulations. According to Aulton (1999) HR values, less than 1.25 indicate good flow, while values greater than 1.25 indicates poor flow. Thus the HR value of $B$. diffusa in the present study was found to be $1.07 \pm 0.41$ indicating good flow rate.

\section{Proximate analyses}

This study is the first report on the detailed proximate analyses of $B$. diffusa. Proximate and nutrient characteristics of any edible plant and vegetables determine their nutritional value $[5,38]$. The low moisture content of the plant B. diffusa in its dry form (13.09\%) indicates an insignificant hygroscopic nature which would ensure resistance to microbial contamination. A high fibre content $(7.1 \pm 0.09 \%)$ makes $B$. diffusa ideal for consumption especially in people with hypercholesterolemia, constipation, etc.

Evaluating the nutrient composition of medicinal plants would help us to understand the nourishment supplemented to the body along with its medicinal properties. Proteins, carbohydrates, fat and minerals including elements and vitamins, contribute to caloric and dietary requirements of human [39]. The high amount of carbohydrate and protein as observed in the present study is an advantage in nutritive aspect over and above its medicinal properties. However, the fat content of the plant was found to be relatively low $(1.61 \mathrm{mg} / \mathrm{gm})$. The present result confirms Ekop, (2007) finding in the case of lipid and Ujowundu et al., (2008) [7] in the case of carbohydrate and protein.
The vitamin analysis in B. diffusa revealed that it is rich in essential vitamins like vitamin A, B complex, C, D and E. The quantity obtained for Vitamin $A$ is $0.91 \pm 0.01 \mathrm{mg} / \mathrm{g}$ and recommended dietary allowance for vitamin A is $1.5 \mathrm{mg} / 100 \mathrm{~g}$. Vitamin A is essential for vision process, bone and teeth formation [40]. Niacine (Vitamin B3) was the major vitamin present in the plant. Niacin plays an important role in energy metabolism, and its daily recommended intake is $1.7 \mathrm{mg}$. Analysis of vitamins in the present study showed that the quantity of thiamine-Vitamin B1 $(0.24 \mathrm{gm} / \mathrm{gm})$, riboflavin-vitamin B2 (0.31 \pm 0.03$)$, ascorbic acid-Vitamin C $(0.20$ $\mathrm{mg} / \mathrm{gm})$, and tocopherol-Vitamin E $(0.16 \mathrm{mg} / \mathrm{gm})$ were moderate in B. diffusa. Thiamine helps in maintaining healthy nerves thereby improving the mental ability. The daily intake of thiamine is 1.2 $\mathrm{mg} / \mathrm{gm}$. Thyroid functioning and wound healing need the vitamin riboflavin-vitamin B2 and the recommended dosage is $1.7 \mathrm{mg} / \mathrm{gm}$. Ascorbic acid prevents free radical damage and triggers the inflammatory responses. Daily recommended dose is $60 \mathrm{mg} / \mathrm{gm}$ [38]. Tocopherol is a lipid soluble antioxidant, protecting cell membranes from oxidation and its recommended level is $25-37 \mathrm{mg}$. The total free amino acids obtained in the present investigation was higher. There is a correlation between amino acid content and radical scavenging activity, thus the higher content of free amino acid is one of the for the plants scavenging capacity.

\section{Mineral analysis}

Generally, minerals from plant sources are less bioavailable than those from animal sources [42]. The quantity of minerals in B. diffusa in the descending order was $\mathrm{Mg}>\mathrm{Na}>\mathrm{Ca}>\mathrm{K}>\mathrm{Zn}>\mathrm{Mn}>\mathrm{Fe}>\mathrm{Cu}>\mathrm{Pb}>\mathrm{Cd}$. The major macro-element present in the plant is Magnesium (Mg). Sodium and potassium are involved in maintaining water and acidbase balance and also involved in the transport of some nonelectrolytes. Calcium is essential for the formation and maintenance of bone beside its blood clotting and muscle contraction processes. High quantity of calcium $69.4 \mathrm{mg} / 100 \mathrm{~g}$ present in the plant indicates its ability to regulate or control the osmotic balance in the body fluid and $\mathrm{pH}$ level in the body. The presence of three essential elements namely iron, manganese and zinc indicate the efficient of enzyme metabolism in B. diffusa. Low concentrations of the heavy metals such as lead, cadmium and copper below the admissible limit suggest its utility in consumption [43]

\section{Determination of antinutrient parameters}

The nutritional importance of a plant also depends on a number of antinutrients present. Antinutrients are usually defined as 'chemical substances in food that do not offer any nourishment to the body'. The estimation of antinutrients in the plant $B$. diffusa revealed that the amount of antinutrients is not up to the toxic limits, suggesting the nutritional worth of the plant. The concentrations of saponin, tannins, oxalates and phytic acid in B. diffusa were however not alarming when compared with their concentrations in other foodstuffs [44]. If the antinutrients are present in large quantities, it lowers the utilisation of elements and nutrients by forming insoluble salts. Thus the plant is ideal for consumption possibly because they do not diminish nutrient availability due to the low amount of antinutrients.

\section{CONCLUSION}

The nutritive analysis of $B$. diffusa indicates a high nutritive and pharmacological value of the plant. The plant screened for physicochemical constituent seemed to have the potential to act as a source of useful drugs and also to improve the health status of the consumers as a result of the presence of various compounds that are vital for good health. The presence of many nutraceuticals, nutrients and antinutrients in extracts with potential clinical relevance play a vital role in preventing various diseases. Being naturally and widely present in the ecosystem, it can be recommended for medication, from which therapeutic drugs can be obtained.

\section{ACKNOWLEDGEMENT}

The authors are grateful to Head, Department of Botany, University of Kerala, Kariavattom for providing the facilities for completing the study. 


\section{CONFLICT OF INTERESTS}

Declared none

\section{REFERENCES}

1. Rodriguez R, Jimenez A, Fernandez-Bolanos J, Guillen R, Heredia A. Dietary fibre from vegetable products as a source of functional ingredients. Trends Food Sci Technol 2006;17:3-15.

2. Springfield EP, Eagles PK, Scott G. Quality assessment of South African herbal medicines by means of HPLC fingerprinting. J Ethnopharmacol 2005;101:75-83.

3. Yelne MB, Sharma PC, Dennis TJ. Database on medicinal plants used in Ayurveda. Vol. 1. Central Council for Research in Ayurveda and Siddha, New Delhi; 2000. p. 360-78.

4. Goyal BM, Bansal P, Gupta V, Kumar S, Singh R, Maithani M. Pharmacological potential of Boerhaavia diffusa: an overview. Int J Pharm Sci Drug Res 2010;2:17-22.

5. Pandey M, Abidi AB, Singh S, Singh RP. Nutritional evaluation of leafy vegetable paratha. J Hum Ecol 2006;19:155-6.

6. Najam A, Singh AK, Verma HN. Ancient and modern medicinal potential of Boerhaavia diffusa and Clerodendrum aculeatum. Res Environ Life Sci 2008;1:1-4.

7. Ujowundu CO, Igwe CU, Enemor VH, Nwaogu LA, Okafor OE. Nutritive and anti-nutritive properties of Boerhavia diffusa and Commelina nudiflora leaves. Pak J Nutr 2008;7:90-2.

8. Mishra S, Aeri V, Gaur PK, Jachak SM. Phytochemical, therapeutic, and ethnopharmacological overview for a traditionally important herb: Boerhavia diffusa Linn. BioMed Res Int 2014:14. Doi:10.1155/2014/808302

9. Wozniak W, Radajewska B, Reszelska-Sieciechowicz A, Dejwor I. Sugars and acid content influence organoleptic evaluation of fruits of six strawberry cultivars from controlled cultivation. Int Strawberry Symposium 1996;439:333-6.

10. World Health Organization WHO. Quality control methods for medicinal plant materials, Geneva, Switzerland; 1998. p. 1-115.

11. Lohar DR, Singh R. Quality control manual for ayurvedic, siddha and unani medicine. Ghaziabad: Department of Ayush, Ministry of Health and Family Welfare, Pharmacopoeial Laboratory for Indian Medicine; 2008. p. 21-4.

12. Indian Pharmacopoeia. Ministry of health and family welfare. Government India 1996;2:350.

13. World Health Organization WHO. Reducing risk, promoting a healthy life. Geneva, Switzerland; 2002.

14. The United States Pharmacopoeia. 26-National formulary 21. Rockville MD: USS pharmacopoeia Convention; 2003.

15. Hausner HH. Friction conditions in a mass of metal powder. Polytechnic Inst. of Brooklyn. Univ. of California, Los Angeles; 1967.

16. Carr, Ralph L. Evaluating flow properties of solids; 1965. p. 163-8.

17. Maynard AJ. Methods in food analysis. Academic Press, New York; 1970. p. 176

18. Hedge JE, Hofreiter BT, Whistler RL, Be Miller JN. Carbohydrate chemistry. Academic Press: New York; 1962. p. 17.

19. Thayumanavan B, Sadasivam S. Physicochemical basis for the preferential uses of certain rice varieties. Plant Foods Hum Nutr 1984;34:253-9.

20. Bradford MM. Rapid and sensitive method for the quantification of microgram quantities of protein utilising the principle of protein-dye binding. Anal Biochem 1976; 72:248-54.

21. Bligh EG, Dyer WJ. A rapid method of total lipid extraction and purification. Can J Biochem Physiol 1959;37:911-7.

22. Adeyemi IA, Omonigbehin AE, Smith S, Oluwatosin O, Jumoke S. Antibacterial activity of extracts of Alchornea cordifolia (Schum and Thonn) Mull. Arg., Boerhavia diffusa (L) and Bridellia micranthal (Hoscht) Baill. Used in traditional medicine in Nigeria on Helicobacter pylori and four diarrhoeagenic bacterial pathoge. Afr J Biotechnol 2008;7:3761-4.

23. Sadasivam S, Manickam A. Biochemicals Methods. New Age International (P) Limited. New Delhi; 2008. p. 4-10.
24. Koche D, Shirsat R, Imran S, Bhadange DG. Phytochemical screening of eight traditionally used ethnomedicinal plants from Akola District (MS) India. Int J Pharm Bio Sci 2010;1:B256.

25. Adepoju OT, Adeniji PO. Nutrient composition and micronutrient potential of three widly grown varieties of African Star apple (Chysophyllum albidum) from Nigeria. Afr J Food Sci 2012;6:344-51.

26. Lai LS, Chou ST, Chao WW. Studies on the antioxidative activities of Hsian-tsao (Mesona procumbens Hemsl) leaf gum. J Agric Food Chem 2001;49:963-8.

27. Moore S, Stein WH. Partition chromatography of amino acids on starch. Ann New York Acad Sci 1948;49:265-78.

28. Gopalan C, Rama Sastri BV, Balasubramanian SC. Nutritive value of Indian Foods (revised and updated by Narasinga Rao, BS, Deosthale, YG, Pant, KC) Hyderabad NIN India; 2004.

29. Allen SE, Grimhaw HM, Parkinson JA, Quarmby C. Chemical analysis of ecological materials. Allen SE. Ed. Black Scintific publications, Oxford, London, Edinburgh, Melbourne; 1984. p. 565.

30. AOAC. Official Method of analysis. $14^{\text {th }}$ edition. Association of official and analytical Chemists, Washington DC; 1990.

31. Ramteke RS, Vijayalakshmi MR, Eipeson WE. Processing and value addition of mangoes. Indian Food Industry 1999; 18:155-63.

32. Mukherjee PK. Quality control of herbal drugs: an approach ro evaluation of botanicals. Horizons; 2002. p. 459.

33. Meena AK, Niranjan US, Yadav AK, Ajit K, Singh B, Kiran RM. A quality assessment of Boerhaavia diffusa Linn. commonly known as 'Punarnava' plant. Int J Pharmacogn Phytochem Res 2010;2:25-8.

34. Malhotra D, Khan A, Ishaq F. Phytochemical screening and antibacterial effect of root extract of Boerhaavia diffusa L. (Family Nyctaginaceae). J Appl Nat Sci 2013;5:221-5.

35. Kala S, Johnson M, Janakiraman, Arockiaraj A, Raj S, Bosco D. Pharmacognostic and phytochemical studies on some selected ethnomedicinal plants of Tamilnadu, South India. Int J Med Aromat Plants 2011;1:2249-4340.

36. Bharathi K, Thirumurugan V, Kavitha M, Muruganadam G, Ravichandran K, Seturaman M. A comparative study on the green biosynthesis silver nanoparticles using dried leaves of Boerhaavia diffusa $\mathrm{L}$. and Cichorium intybus $\mathrm{L}$. with reference to their antimicrobial potential. World J Pharm Sci 2014;3:1415-27.

37. Aulton ME. Pharmaceutics; the science of dosage form design. Churchill Living Stone Edinburgh 1999;205:247-312.

38. Nyambo A, Nyamora A, Ruffo CK, Tengnas B. Technical handbook on fruits and nuts. Species with potential for Tanzania; World Agroforestry; 2005. p. 139-45.

39. Underwood EJ. Trace Elements in Human and Animal Nutrition New York; 1977.

40. Ekop AS. Determination of the chemical composition of Gnetum africanum (AFANG) seeds. Pak J Nutr 2007;6:40-3.

41. Umadevi M, Sampath Kumar KP, Debjit Bhowmik, Duraivel S. Traditionally used anticancer herbs in India. J Med Plant Studies 2011;1:56-7.

42. Oki T, Masuda M, Furuta S, Nishibia Y, Terahara, Suda I. Involvement of anthocyanins and other phenolic compounds in the radical scavenging activity of purple-fleshed sweet potato cultivars. Food Chem Toxicol 2002;67:1752-6.

43. Subramanian R, Gayathri S, Rathnavel C, Raj V. Analysis of mineral and heavy metalsin some medicinal plants collected from the local market. Asian Pac J Trop Biomed 2012:S74-S78.

44. Chakraborty ER, Eka OU. Studies on hydrocyanic, the oxalic and phytic content of foodstuffs. West Afr J Biol Appl Chem 1978;21:43-52.

\section{How to cite this article}

- Juna Beegum GR, Sugunan VS, S Suhara Beevy. Neutracuetical evaluation of Boerhavia diffusa L. Int J Curr Pharm Res 2017;9(1):101-104. 